\title{
KIHÍVÁSOK ÉS ÚJ LEHETŐSÉGEK A GEOTERMIKUS ENERGIA HASZNOSÍTÁSÁNAK NÖVELÉSÉBEN
}

\section{CHALLENGES AND NEW OPPORTUNITIES IN INCREASING GEOTHERMAL ENERGY UTILIZATION}

\author{
Szű́cs Péter ${ }^{1, a, b}$, Madarász Tamás ${ }^{2, a}$, Hartai Éva ${ }^{3, a}$, Kolencsikné Tóth Andrea ${ }^{4, a}$, Zákányi Baláz5 ${ }^{5, a}$

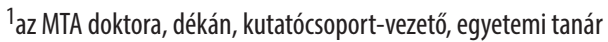 \\ ${ }^{2} \mathrm{PhD}$, intézetigazgató, egyetemi docens \\ ${ }^{3} \mathrm{PhD}$, címzetes egyetemi tanár \\ ${ }^{4} \mathrm{PhD}$, egyetemi adjunktus \\ ${ }^{5} \mathrm{PhD}$, egyetemi docens \\ aMiskolci Egyetem Mǘszaki Földtudományi Kar, Miskolc \\ ${ }^{\text {b} M T A-M E ~ M u ̈ s z a k i ~ F o ̈ l d t u d o m a ́ n y i ~ K u t a t o ́ c s o p o r t, ~ M i s k o l c ~}$ \\ hgszucs@uni-miskolc.hu
}

\begin{abstract}
ÖSSZEFOGLALÁS
Magyarország geotermikus természeti adottságai köztudottan igen jónak tekinthetők. A tanulmány arra keres választ, hogy milyen irányok mentén növekedhet a hazai geotermikus energia felhasználása, milyen akadályozó tényezőket és kihívásokat szükséges megoldani kutatás-fejlesztés segítségével a potenciális beruházók részére annak érdekében, hogy új lehetőségek nyíljanak a geotermikus energia hasznosítására.
\end{abstract}

\section{ABSTRACT}

It is a well-known fact that the geothermal energy potential is very high in Hungary. The main aim of this paper is to give potential directions where the geothermal energy utilization can be increased significantly in Hungary in the future. In addition, some natural and technical challenges are also outlined, which can be solved by intense research and innovation activity.

Kulcsszavak: geotermikus energia, hévíz, hidrotermális rendszerek, fenntarthatóság, geotermikus erőmű

Keywords: geothermal energy, thermal water, hydrothermal systems, sustainability, geothermal power plant 


\section{A GEOTERMIKUS ENERGIA HELYE ÉS SZEREPE AZ ENERGIAELLÁTÁSBAN}

A következő időszakban a világ energiaellátásában igen jelentős átalakulás várható. A szigorodó környezetvédelmi elöírások, valamint a dekarbonizációs törekvések hatására a megújuló energia felhasználása egyre nagyobb arányúvá válik az Európai Unióban, valamint a fejlett gazdaságú országokban. Bár a kutatás-fejlesztés egyre nagyobb hányada a megújuló energiafajták térnyeréséhez kötődik, az világosan látszik, hogy a következö évtizedekben sem lehetünk meg szén és szénhidrogének nélkül. 2016-ban a világ energiafelhasználásának 28\%-a szénre épült, és $57 \%$-ot ért el a kőolajra és földgázra alapozott energiafelhasználás. Ugyancsak 2016-ban a megújuló energiák részaránya még csupán 3,2\%-ot tett ki a teljes földi energiafelhasználásban. Európában a helyzet jobb a megújulók vonatkozásában: 2017-ben az uniós energiamixben a megújulók részaránya elérte a 30\%-ot. Európában jelenleg a szél- és a vízenergia hasznosítása a legjelentősebb a tiszta energiák közül. A geotermikus energia helyét és szerepét ebben a környezetben kell megítélni. A geotermikus energia nagyon fontos, de globális léptékben egyelöre nem meghatározó tényező. A megújuló energiafajták közül például a napenergia felhasználása sokkal dinamikusabban nő, mint a geotermikus energiáé. A világszerte üzemelö fotovoltaikus erőmüvek összesített kapacitása exponenciálisan nő. 2021-ben a várható kapacitás optimista becslés szerint elérheti a 935,5 GW értéket, de pesszimista becslés esetén is legalább 623,2 GW értékkel kalkulálhatunk.

Ezzel szemben a geotermikus erömüvi kapacitások növekedése csak igen lassú ütemü a világban. 2017-ben az összesített, világszerte üzemelő geotermikus erőmüvi kapacitás $14 \mathrm{GW}$ volt, de a 2020-ra prognosztizált értéke sem nagyobb 18 GW-nál. Európában természetesen komolyan tekintünk a geotermikus energiára épülő villamosáram-termelés jövőbeli növekedésére, amelynek értéke 2017-ben 2,3 GW volt, míg 2030-ban 10 GW kapacitásra számíthatunk. A geotermikus energia igen alacsony környezetterhelést okozó felhasználása elsősorban a lokális energiaigények kiszolgálásában, a külföldi energiafüggőség csökkentésében játszhat jelentős szerepet. Az azonban irreális elvárás lenne, ha például a hazai áramellátást teljes mértékben geotermikus erőművek telepítésével kívánnánk megoldani a következő harminc évben. Az is világosan látszik, hogy további igen komoly kutatás-fejlesztésre és innovációra van szükség ahhoz, hogy a geotermikus energia felhasználása jelentős mértékben növekedhessen akár hazánkban, akár globális léptékben. Számos hazai pályázat (Szücs et al., 2013), szakmai tanulmány (Mádl-Szőnyi et al., 2015), valamint a felszín alatti vizek kutatásának európai léptékü vizsgálatával foglalkozó KINDRA H2020 projekt (URL1) eredményei is egyértelműen bizonyítják, hogy Európában az utóbbi évtizedben jelentősen fokozódik a kutatási tevékenység a geotermikus energia teljes spektrumát illetően (Fernandez et al., 2017). Ebben a hazai szakemberek széles körü nemzetközi elismertséget szereztek. 


\section{KIHÍVÁSOK ÉS LEHETŐSÉGEK A HAZAI GEOTERMIKUS ENERGIA FELHASZNÁLÁSÁNAK NÖVELÉSÉBEN}

Számos kiváló és átfogó tanulmány ad részletes képet a geotermikus energia hazai potenciáljáról regionális és lokális léptékben is (Bobok-Tóth, 2010; Székely, 2010). A jelenlegi helyzet elemzésével összességében azonban megállapítható, hogy a geotermikus energiát hasznosító létesítmények kapacitása sokkal nagyobb is lehetne hazánkban a természeti adottságok figyelembevételével. Közismert, hogy a geotermikus potenciált tekintve kiemelkedőek a Kárpát-medence természeti adottságai. A geotermikus hő hasznosítása tekintetében Magyarország az előkelő negyedik helyen áll Európa országai között. Jelenleg közel 800 MW a geotermikus hő hasznosítására szolgáló kapacitásunk, amelynek döntő része a kommunális fütésben és a mezőgazdaságban hasznosul. A geotermikus energia hasznosításának gyökerei és kezdeti legfontosabb eredményei hazánkban leginkább Délkelet-Magyarországhoz köthetők (Szanyi-Kovács, 2010). A jelenlegi rendszerek hidrotermális rendszereknek tekinthetők (Székely et al., 2015), hiszen a geotermikus energia a felszín alatti kőzetekben tárolt hévíz segítségével jut el a felszínig. Komoly probléma, hogy az energetikai célból felhasznált hévizeknek alig 10\%-át sajtolják vissza. A fenntarthatósági aspektusok és a felszín alatti vízkészleteink védelme (Somlyódy, 2011) érdekében fontos megjegyezni, hogy a természetes módon igen korlátozottan utánpótlódó hidrotermális rendszereink nem terhelhetők a végtelenségig (Szücs et al., 2015b). Ezért lenne fontos, hogy az energetikai célból felhasznált hévizek esetében sokkal nagyobb mértékủ legyen a visszasajtolás. Jó példa az a néhány évvel ezelőtt indult miskolci beruházás, amelynek eredményeként Közép-Európa legnagyobb geotermikus fütési kapacitása valósult meg $60 \mathrm{MW}$ értékkel, valamint 100\%-os visszasajtolással a bükki hévizes karsztvízrendszerbe. A jelenleg is futó monitoring program a rendszer biztonságos és fenntartható működését mutatja. Ez nagyon fontos, hiszen a környéken számos gyógyfürdő is található, amelyek ugyancsak a Bükk hévizes rendszeréből nyerik a vizüket.

Hazánkban a felszín alatt 2500 méternél mélyebb térrészek geotermikus energiájának hasznosítása csak kijelölt koncessziós területeken lehetséges. A geotermikus alapú áramtermelés kialakítására hazánkban leginkább ezek a területek lehetnek a legalkalmasabbak. A tizenöt kijelölt koncessziós terület részletes érzékenységi vizsgálatai elkészültek, ezek elérhetőek a Magyar Bányászati és Földtani Szolgálat honlapján. Ezek a letölthető dokumentumok igen értékes összeállítások, hiszen a potenciális befektetők és a szakemberek számára komolyan segíthetik a döntés-előkészítést. A Battonya koncessziós területen például egy EGS-rendszerü geotermikus erőmü kialakítása folyik. Az eu-fire.hu honlapon (URL2) információt találunk arról, hogy egy ORC-típusú geotermikus erőmü megvalósítása a cél 11,8 MW áramtermelési és további $62 \mathrm{MW}$ hőtermelési kapacitással. Az érzékenységi vizsgálatokból és az egyéb hidrogeológiai adatbázi- 
sokból megállapíthatjuk, hogy a hazai hévizek igen változatos vízkémiai összetételủek. A változatos kémiai összetétel mellett gyakran igen magas, 20-30 g/1 oldottanyag-koncentrációk fordulnak elő, amelyek müszaki szempontból igen nehézzé teszik a geotermikus energia hasznosítását. A hazai hévizek összetételéből adódó korróziós és vízkövesedési problémák hatékony kezelése igen komoly technológiai kihívások elé állítja a felhasználókat. Jellemző az egyedi és sokszor esetleges megoldások kialakítása a különböző helyszínek esetében, legyen szó akár kémiai adalékok, korróziós inhibitorok, akár mágneses módszerek alkalmazásáról. Világosan látszik, hogy igen komoly $\mathrm{K}+\mathrm{F}+\mathrm{I}$-igény van ezen a területen a felhasználók részéről, hogy csökkenteni lehessen a korrózió és a vízkövesedés által okozott problémákat.

A geotermikus energia hasznosításának növekedésére érdemben akkor számíthatunk, ha sikerül jelentősen csökkenteni a beruházási kockázatokat és a költségmegtérülés idejét. E tekintetben nagyon fontosak azok a jelenleg is futó európai H2020 kutatási pályázatok, amelyek a geotermikus energia hasznosításának területén kívánnak úttörő fejlesztéseket bevezetni. Ezek közül kiemelhető a CHMP2030 kutatási projekt, amelynek esetében a tizenkét tagú nemzetközi konzorciumot egy magyar intézmény, a Miskolci Egyetem vezeti. A CHPM2030 kutatási projekt célja az, hogy a geotermikus áram- és hőtermelés mellé még fémkinyerést is társítson, és ezáltal még inkább nyereségessé váljon egy geotermikus beruházás.

\section{A CHPM2030 PROJEKT FŐBB CÉLKITÚZÉSEI ÉS INNOVATIV MEGOLDÁSAI}

A CHPM2030 (Combined Heat, Power and Metal Extraction) az Európai Bizottság Horizon 2020 programja által finanszírozott kutatási projekt, amely egy új és várhatóan forradalmi technológia kifejlesztését és az azt megalapozó alapkutatásokat tủzte ki célul egy technológiai folyamatban kapcsolva össze az európai energia- és stratégiai fémszükségletek kielégítését (URL3-6). A geotermikus erőforrások fejlesztése, a fémkitermelés és kohászat határterületein tevékenykedve a projekt nagy mélységü, hagyományosan nem bányászható, fémtartalmú ásvány-előfordulásokat kíván EGS- (Enhanced Geothermal System) rendszerré fejleszteni (orebody-EGS), amely a geotermikus adottságainál fogva villamosenergia-termelés mellett kioldott fémek felszínre hozatalával és felszíni leválasztásával javíthatja a rendszer gazdaságossági mutatóit, és segítheti a beruházási költségek gyorsabb megtérülését. A technológia szabályozása által - az elképzelések szerint - az üzemeltető alkalmas lesz a CHPM-erőmü kapcsolt energia- és fémtermelésére, valamint a piac igényeihez való optimalizálására is.

A fejlesztés kezdeti szakaszában a Miskolci Egyetem által vezetett konzorcium tagjai az európai földtani, geotermikus adatok összegyüjtése, rendszerezése 
mellett egy intenzív és szisztematikus laboratóriumi kísérleti programot hajtottak végre. A kutatási program föbb elemeit az 1. ábra mutatja be. A technológia megvalósítását az alábbi feltételezések igazolhatósága befolyásolja:

- Az érctestek összetétele és szerkezete bizonyos előnyös tulajdonságokat mutat, amelyek EGS-rendszerek szolgálatába állíthatók.

- Fémek érdemi koncentrációban folyamatosan oldhatók ki az érctestből, hozzájárulva ezzel az EGS-rendszer gazdaságos müködéséhez, és elösegítve a kezdeti beruházási költségek gyorsabb megtérülését.

- A folyamatos fémkioldás idővel növelheti a rendszer teljesítményét, minimalizálva a hö- és a fémkinyerés kockázatát.

- A geotermikus fluidumban oldott fémek a felszínre hozhatók, és a felszíni technológiák segítségével leválaszthatók, kinyerhetők.

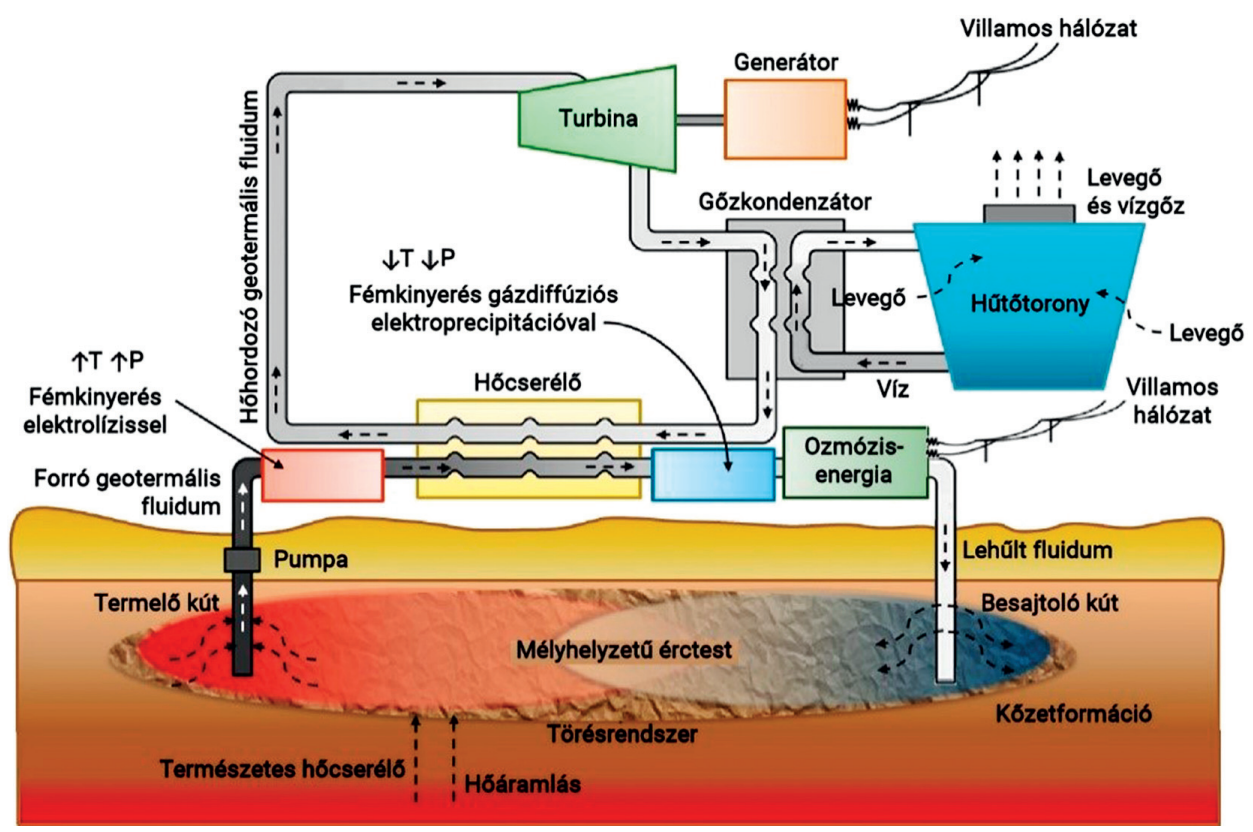

1. ábra. A CHPM-technológia sematikus ábrája, az egyes technológiai elemek helye a folyamatban

(saját szerkesztés)

Jelenleg a jövőbeli CHPM-erőmủ megvalósítását megalapozó laboratóriumi kísérletek folynak, amelyek a különbözö összetételü, állapotú és érctartalmú minták kioldási körülményeit vizsgálják változó hőmérsékleti és nyomásviszonyok (70-200 ${ }^{\circ} \mathrm{C}$; > 200 bar) mellett, többek között füthető szakaszos (batch) reaktorban és autokláv berendezésekben. A kísérletek a British Geological Survey és a Szegedi 
Tudományegyetem laboratóriumaiban folynak. A kioldás egyik kritikus kérdése a geotermikus kútpár által cirkuláltatott munkafolyadék összetétele, amely a hő és oldott fém szállításának közege lesz, de egyben a környezeti terheléssel szemben támasztott szigorú kritériumoknak is meg kell felelnie. Az eddigi kioldási vizsgálatok kedvező eredményeket mutattak híg ecetsav vagy EDTA- (etilén-diamin-tetraecetsav) oldószer alkalmazásakor. A Miskolci Egyetem Müszaki Földtudományi Karának mérnökei a Szegedi Tudományegyetem kutatóival közösen az EGS felszín alatti „,hőcserélője” repedésrendszerének kialakításához újszerü, nagy pontosságú és energiasürüségủ lézer alkalmazhatóságát tesztelik. A felszíni nagy nyomású és magas hőmérsékletủ elektrolitikus fémleválasztás módszertanát a Leuveni Katolikus Egyetem, míg az alacsony nyomás- és hőmérsékleti tartományban megvalósítandó gázdiffúzióval támogatott elektroprecipitációt és a másodlagos energiatermelés módszerét a belga VITO-kutatóintézet elektrokémiai kutatólaborjaiban végzik.

A kutatás alacsony TRL- (technology readiness level) szintje azt is jelenti, hogy az egyes technológiai elemek sikeres fejlesztése, kidolgozása még nem garantálja az egész eljárás sikerességét. A laboratóriumi kísérletek félüzemi, majd ipari szintre történő „,elnagyítása” és az egyes technológiai elemek összekapcsolhatóságának szabályozása komoly mérnöki és modellezési kihívások elé állítja a kutatókat. Ezt a munkafolyamatot az ISOR izlandi geotermikus mérnöki iroda technológus specialistái koordinálják. A müszaki fejlesztések mellett szükséges figyelmet szentelni a technológiai fejlesztés környezeti és gazdasági hatásainak/ feltételeinek vizsgálatára is, ezért a környezeti, gazdasági, társadalmi hatások vizsgálata és modellezése is a projekt feladatai közé tartozik.

Az egyes technológiai építőelemek alkalmazhatósága, CHPM üzembe bevonása megköveteli azok müködési paramétereinek összehangolását. A legfontosabb üzemi paraméterek (munkaközeg összetétele, redoxpotenciál és $\mathrm{pH}$, hőmérséklet- és nyomástartomány, hozam stb.) meghatározása és egymáshoz illesztése, rendszerdinamikai modellezése általános körülményekre nem végezhetö el. Fontos, hogy valós szcenáriók esetére (konkrét pilotterületek adottságait vizsgálva) környezeti és mérnöki peremfeltételek mellett tudjuk modellezni az eljárás müködését. A szcenáriók azonosításának fontos lépése a konkrét pilotterületekröl származó kőzetminták és geotermikus fluidumok elemzésbe vonása, ez a projekt sikerének fontos mérföldköve.

\section{ÖSSZEFOGLALÁS}

A rendelkezésre álló információk és trendek alapján megállapíthatjuk, hogy a geotermikus energia felhasználásának mértéke jelentősen növelhető a jövőben Magyarországon. A hőhasznosítás mellett egyre nagyobb szerepet kell kapnia a geotermikus alapú áramtermelésnek, amelynek nagysága elérheti a száz $\mathrm{MW}_{\mathrm{e}}$ 
nagyságrendet is a következő egy-két évtizedben. E fontos cél eléréséhez intenzív $\mathrm{K}+\mathrm{F}+\mathrm{I}-$ tevékenységre van szükség a felhasználást jelenleg akadályozó kihívások és technológiai problémák hatékony kezelésére. Feltétlenül figyelembe veendö szempont, hogy hazánkban konkuráló hévízfelhasználás van, balneológiai és energetikai célú hasznosítással (Szücs et al., 2015a). Az igen értékes, de korlátozottan utánpótlódó hévizeink esetében különösen tekintettel kell lenni a fenntarthatósági aspektusokra (Buday et al., 2015). A lehetséges kutatási területek közül kiemelhető a geotermikus fluidumok összetett vizsgálatának szükségessége. Innovatív müszaki és természettudományos megoldásokra van szükség annak érdekében, hogy a geotermikus beruházások kockázata csökkenjen, megtérülési ciklusuk pedig rövidüljön a jövőben.

\section{KÖSZÖNETNYILVÁNITÁS}

A tanulmány a „Földi energiaforrások hasznosításához kapcsolódó hatékonyságnövelő mérnöki eljárások fejlesztése" címü GINOP-2.3.2-15-2016-00010 projekt részeként - az Új Magyarország Fejlesztési Terv keretében - az Európai Unió támogatásával, az Európai Szociális Alap társfinanszírozásával valósult meg.

\section{IRODALOM}

Bobok E. - Tóth A. (2010): A geotermikus energia helyzete és perspektívái. Magyar Tudomány, 171, 8, 926-936. http://www.matud.iif.hu/2010/08/04.htm

Buday T. - Szúcs P. - Kozák M. et al. (2015): Sustainability Aspects of Thermal Water Production in the Region of Hajdúszoboszló-Debrecen, Hungary. Environmental Earth Sciences, 74, 7513-7521. http://midra.uni-miskolc.hu/document/20841

Fernandez, I. - Petitta, M. - Hinsby, K. et al. (2017): The KINDRA Project - towards Open Science in Hydrogeology for Higher Impact. European Geologist, 44, Nov., 39-43. https:/eurogeologists.eu/fernandez-kindra-project-towards-open-science-hydrogeology-higher-impact/

Mádl-Szőnyi J. - Pulay E. - Tóth Á. et al. (2015): Regional Underpressure: A Factor of Uncertainty in the Geothermal Exploration of Deep Carbonates, Gödöllő Region, Hungary. Environmental Earth Sciences, 74, 12, 7523-7538. https://www.researchgate.net/publication/279206572_Regional_underpressure_a_factor_of_uncertainty_in_the_geothermal_exploration_of_deep_carbonates_Godollo_Region_Hungary

Somlyódy L. (szerk.) (2011): Köztestületi Stratégiai Programok. Magyarország vízgazdálkodása: helyzetkép és stratégiai feladatok. Budapest: MTA, http://old.mta.hu/data/Strategiai_konyvek/ viz/viz_net.pdf

Szanyi J. - Kovács B. (2010): Utilization of Geothermal Systems in South-East Hungary. Geothermics, 39, 357-364. DOI: 10.1016/j.geothermics.2010.09.004, https:/www.researchgate.net/ publication/222010593_Utilization_of_geothermal_systems_in_South-East_Hungary

Székely F. (2010): Hévizeink és hasznosításuk. Magyar Tudomány, 171, 12, 1473-1485. http:// www.matud.iif.hu/2010/12/08.htm 
Székely F. - Szücs P. - Zákányi B. et al. (2015): Comparative Analysis of Pumping Tests Conducted in Layered Rhyolitic Volcanic Formations. Journal of Hydrology, 520, 180-185. DOI: 10.1016/j. jhydrol.2014.11.038, http://193.6.1.94:9080/JaDoX_Portlets/displayContent?docId=22603\&secId $=17082$

Szücs P. - Fejes Z. - Zákányi B. et al. (2015a): Results of the WELLaHEAD Project Connected to Water and Mining. Geothermal Potential of the Tokaj-Mountains. Pilot Test of Passive Acid Mine Drainage Water Management. FOG - Freiberg Online Geology, 40, 170-177. http://midra.uni-miskolc.hu/document/22600/17079.pdf

Szücs P. - Kompár L. - Palcsu L. et al. (2015b): Estimation of Groundwater Replenishment Change at a Hungarian Recharge Area. Carpathian Journal of Earth and Environmental Sciences, 10 , 4, 227-246. http://midra.uni-miskolc.hu/document/22607?docID=22607\&setFontSize=small

Szücs P. - Virag M. - Zákányi B. (2013): Investigation and Water Management Aspects of a Hungarian-Ukrainian Transboundary Aquifer. Water Resources, 40, 4, 462-468. https://www.researchgate.net/publication/257846910_Investigation_and_water_management_aspects_of_a_ Hungarian-Ukrainian_transboundary_aquifer

URL1: KINDRA H2020 projekt: kindraproject.eu

URL2: www.eu-fire.hu

URL3: CHPM Consortium: EGS-Relevant Review of Metallogenesis; Deliverable D1.1; Dec. 2016, http://www.chpm2030.eu/wp-content/uploads/2017/02/CHPM2030_D1.1_public.pdf

URL4: CHPM Consortium: Conceptual Framework for Orebody-EGS CHPM2030 Deliverable D1.4; Dec. 2016, https://www.chpm2030.eu/wp-content/uploads/2017/02/CHPM2030_D1.4_ public.pdf

URL5: CHPM Consortium: Report on Metal Content Mobilisation Using Mild Leaching; Deliverable D2.2; Dec. 2016, https://www.chpm2030.eu/wp-content/uploads/2018/03/CHPM2030_ D2.2.pdf

URL6: CHPM Consortium: D2.4 Report on Overall Systems Dynamics; Deliverable D2.4; Dec. 2016, http://www.chpm2030.eu/wp-content/uploads/2018/03/CHPM2030_D2.4.pdf 